\title{
Dvije đatake o gušteru
}

\section{Đātaka o gušteru (1)}

Redovnici upitaše Blaženoga: „Zašto, Blaženi, Yaśodharā nije mogla biti zadovoljna? Kad si kao mladić dijelio nakit djevojkama, Yaśodhari si dao ogrlicu vrijednu sto tisuća novčića, a ona je rekla: 'Zar samo toliko vrijedim?' Dao si joj još i prsten vrijedan sto tisuća novčića, ali ni tad nije bila zadovoljna. Zašto je Yaśodharā bila nezadovoljna i oneraspoložena?"

Blaženi odgovori: „Nije to, redovnici, prvi put da je Yaśodharā bila nezadovoljna. I prije je bila nezadovoljna.

Nekoć davno, u gradu Benaresu pokrajine Kāśi, vladao je, redovnici, kralj Suprabha. Imao je sina Suteđasa, koji je bio obdaren mnogim vrlinama. Bio je vrlo snažan, miran, ugodan, nenametljiv i pristojan u razgovoru. Cijenili su ga i uvažavali ministri, zapovjednik vojske i seoski poglavari pa je kralj jednom pomislio: 'Sav narod cijeni vrline toga princa. Da me neće jednoga dana ubiti pa njega postaviti na prijestolje?' I tako je kralj odlučio izgnati princa.

$\mathrm{Na}$ čistini kraj šumarka, negdje na Himalaji, prognani princ i njegova supruga izgradili su kolibu od trave i lišća. Hranili su se korijenjem, lišćem, voćem i vodom, a ako bi imali sreće, i mesom jelena i divljih svinja. Jednom, za vrijeme prinčeva izbivanja iz kuće, mačka je ubila krupnog guštera, donijela ga njegovoj supruzi pred noge i otišla. Žena ga nije htjela ni dotaknuti. Princ se domala vratio s korijenjem, lišćem i voćem. Ugledavši golemog, debelog guštera, upita princezu: 'Otkud ovaj gušter?'

'Mačka ga je donijela', odgovori ona.

'Zašto nije pripremljen?' upita opet princ. Ona mu odgovori: 'Zato što ne vrijedi ni kravlje balege.' 'Nije nejestiv, ljudi jedu guštere', rekao je princ i oderao guštera da ga pripremi za jelo. 
Princ je potom skuhao guštera i objesio ga o granu stabla. Princeza je pak uzela krčag da donese vode i otišla rekavši: 'Idem po vodu pa ćemo jesti.' Vidjevši pripremljenog guštera, dobre boje i mirisa, mekog i svježeg, javila joj se želja za jelom. Princ je međutim pomislio: 'Princeza nije htjela ni prstom dotaknuti sirovog guštera, a sad ga skuhanog želi jesti. Da me imalo voli, ona bi ga bila skuhala dok sam bio u potrazi za voćem. Zato ga neću s njom podijeliti, već ću ga sam pojesti.' Dok je princeza grabila vodu, on je pojeo guštera. Vrativši se s krčagom vode, princeza upita princa: 'Poštovani, gdje je gušter?'

'Pobjegao je', odgovori joj princ.

'Kako je gušter, skuhan i zavezan, mogao pobjeći?' pomisli princeza. Kad je zaključila da je princ ne voli, tuga joj uđe u srce.

Kraj je života smrt i svako će biće umrijeti.

Po svome će djelu dobro il' zlo bića zaslužiti.

Pakao čeka zle, a nebo one zasluga dobrih.

Tko usavrši Put, oslobodit će se djela loših.

U to je vrijeme kralj Suprabha podlegao sudbini smrtnika, pa su ministri pozvali princa Suteđasa da se vrati iz šume i postavili ga na prijestolje. Sve što je posjedovao i što je u kraljevstvu bilo vrijedno kralj Suteđas stavio je na raspolaganje kraljici. Donosio joj je divne tkanine, ukrase, ogrlice i narukvice, ali je nije mogao razveseliti jer joj je onaj gušter još ležao na srcu.

'Ni ljubaznost koju sam joj učinio, ni ljubav koju sam joj pokazao ne mogu razveseliti kraljicu', pomisli kralj. Jednom joj se prilikom obratio: 'Ne veseli te ni ljubaznost koju sam ti učinio, ni ljubav koju sam ti pokazao. Objasni, ne razumijem!' Kraljica je kralju Suteđasu odgovorila stihovima:

Pamtim, mužu, što se onomad u šumi dogodilo.

Kraj tebe snažnog, još s lukom i strijelom o pasu,

Pobježe skuhani gušter konopom vezan o granu!

Kralj odgovori:

Poštuj časnoga, daj davateljima. 
Čini dobro dobročiniteljima.

Ne da li tebi, ni ti nemoj dati.

Kad ptica ploda na stablu ne nađe,

Shvati 'svijet je velik' pa otprhne.

Mogli biste pomisliti, redovnici, da je u ono vrijeme i onom prilikom kralj Suteđas bio netko drugi.

No nemojte tako misliti. Zašto? U ono vrijeme i onom prilikom ja sam bio kralj Suteđas. Mogli biste pomisliti da je kraljica kralja Suteđasa bila neka druga. Nemojte tako misliti. Yaśodharā je, redovnici, bila kraljica kralja Suteđasa. I tada je bila nezadovoljna i nije se mogla razveseliti. I sad je bila nezadovoljna i nije se mogla razveseliti."

Tako završava đātaka o gušteru.

\section{Đātaka o gušteru (2)}

Ovu pripovijest, vezanu uz jednog prevaranta, Učitelj je ispričao u gaju Đeti. Tom su prilikom redovnici doveli jednog od njih optuženog za prevaru i pokazali ga Učitelju.

„Poštovani”, rekoše, „ovaj je redovnik prevarant.”

„Nije tom redovniku prvi put da je prevarant”, reče na to Učitelj i ispriča priču iz prošlosti.

„Jednom davno, u vrijeme Brahmadattine vladavine Benaresom, Bodhisatta se rodio kao gušter. Bio je razvijen i snažnoga tijela, a živio je u šumi. U blizini se nastanio neki iskvareni isposnik, sagradivši si kolibu od lišća. Dok je lutao u potrazi za hranom, Bodhisatta ugleda tu kolibu od lišća. Pomisli: 'Bit će da je to koliba nekog svetog isposnika.' I tako je dolazio do kolibe pa se, uljudno pozdravivši isposnika, vraćao u svoju nastambu. Jednoga dana zli je isposnik posjetio kuću svoga pokrovitelja i ondje dobio sočan komad mesa.

'Kakvo je ovo meso?' upita.

Čuvši od domaćina da jede gušterovo meso, polakomi se: 'Ubit ću onog guštera koji stalno dolazi do moje kolibe pa ću ga skuhati po svom ukusu i pojesti.' 
Pripremio je maslac, kiselo mlijeko, začine i ostalo pa sjeo na dovratak kolibe mirno iščekujući dolazak guštera. Teški je malj sakrio pod svoju narančastu isposničku halju. Kad je došao i ugledao tog pokvarenjaka, Bodhisatta pomisli: 'Izgleda kao da se najeo mesa moje vrste. Provjerit ću...' Stao je niz vjetar i onjušio isposnika. Odmah je znao da se taj najeo mesa guštera pa se dao u bijeg, što dalje od isposnika. Kad je vidio da gušter bježi, isposnik je za njim bacio malj. Promašio je tijelo, ali mu je okrznuo vrh repa.

'Mene jesi, ali tebe neće promašiti četverovrsna patnja!' odgovorio mu je Bodhisatta i pobjegao. Nestavši u mravinjaku koji je stajao na kraju šetnice, pomoli glavu iz neke rupe i uputi isposniku dvije strofe:

Isposništvom ti se hvališ, a nad sobom nemaš vlasti.

Štap si na me bacio i pravo lice pokazao.

Čemu služe zamršene lokne, čemu halje kožne?

Iznutra ti si pokvaren, a izvana sav ulašten.

Kad je to čuo, isposnik izreče treću strofu:

Vrati se gušteru i uskoči u rižu kuhanu!

Ne manjka mi ulja, soli nit' me zrno papra boli.

Bodhisatta odgovori četvrtom strofom:

Pobjeći ću dalje, skrit se u visoke kuće mravlje.

Čuvaj za se ulje, sol, a i papar ja prezirem skroz.

To izrekavši, još mu i zaprijeti: 'Fuj, pokvareni isposniče! Ostaneš li ovdje, prokazat ću te kao varalicu i dati da te uhvate ljudi koji žive na zemlji kojom lutam u potrazi za hranom. Smjesta bježi!' Pokvareni se isposnik istoga trena dao u bijeg."

Završivši s poukom, Učitelj zaključi pripovijest: „U ono je vrijeme redovnik - prevarant bio pokvareni isposnik, a ja sam bio kralj guštera."

Tako završava đātaka o gušteru. 


\section{(c) (i) (9)}

Creative Commons Attribution-NonCommercial-NoDerivatives 4.0 International License 